\title{
EVALUATION OF DENTAL STATUS AND EFFECTIVENESS OF TREATMENT AMONG CHILDREN AND ADOLESCENTS IN THE REFERENCE GROUPS AGED 6, 12, AND 18 YEARS FROM SKIERNIEWICE AND ITS REGION IN 2017-2020
}

\author{
STAN UZĘBIENIA I OCENA SKUTECZNOŚCI LECZENIA DZIECI I NASTOLATKÓW \\ W GRUPACH REFERENCYJNYCH 6, 12 I 18 LAT ZE SKIERNIEWIC I OKOLIC \\ W LATACH 2017-2020
}

\author{
Department of Conservative Dentistry, Medical University of Lodz \\ Uniwersytet Medyczny w Łodzi, Zakład Stomatologii Zachowawczej
}

\section{ABSTRACT}

INTRODUCTION. Dental caries is a transmissible chronic disease of dental hard tissues. To monitor the course of carious process, age reference groups were designated which are subject to regular dental check-ups. The groups include children aged 6,12, and 18 years as well as adults at the age of 35-44 and 55-64 years.

AIM. The aim of the study was to evaluate the state of dentition and effectiveness of treatment among children and adolescents in the reference groups aged 6,12, and 18 years from the town of Skierniewice and its region in the years 2017-2020.

MATERIAL AND METHODS. The study included 385 children and adolescents from the reference groups. Dental examination was carried out in the dental office of the Ogrodowa Medical Centre in Skierniewice. Dental caries intensity expressed by the the DMFT index, and its particular components, D, M, and F (D- the mean number of teeth with caries (decayed), M- teeth extracted (missing), and F- filled) as well as the dental caries treatment index DTI $(\mathrm{F} /(\mathrm{D}+\mathrm{F}))$ were determined according to sex.

RESULTS. Distribution of the DMFT index components was very similar in children aged 6 years and in 18-year-old adolescents. The D component constituted half the DMF index $(50.7 \%$ in 6 -year-olds and 52.4\% in 18-year-olds), the $\mathrm{M}$ component values were lowest (16.1\% and $12.3 \%$, respectively) while the $\mathrm{F}$ component accounted for slightly more than $1 / 3$ of the whole value (33.2\% and $35.3 \%$, respectively). In 12 -year-olds, the D component value was $68.4 \%$ of the DMF index, the M component accounted for only a few percent (4.5\%) and the F component was $27.1 \%$. The DTI value was 0.40 for 6-year-olds and 18 -year-olds and appeared to be significantly higher than in the group of 12-year-olds (0.3).

CONCLUSIONS. There is an urgent need for monitoring the dental status, professional caries prevention, and conservative treatment of teeth in children and adolescents of the Skierniewice region.

Key words: reference groups, dental caries, treatment index, children and adolescents

\section{STRESZCZENIE}

WSTĘP. Próchnica jest transmisyjną, przewlekłą chorobą twardych tkanek zęba. W celu monitorowania przebiegu procesu próchnicowego wyznaczono referencyjne grupy wiekowe poddawane regularnym przeglądom stomatologicznym. Są to dzieci w wieku 6, 12, 18 lat oraz osoby dorosłe w wieku 35-44 i 55-64. CEL. Celem pracy była ocena stanu uzębienia i efektywności leczenia dzieci i młodzieży w grupach referencyjnych 6, 12 i 18 lat ze Skierniewic i okolic w latach 2017-2020.

MATERIAL I METODY. Badaniu poddano 385 dzieci i młodzież z grup referencyjnych. Badania przeprowadzono w gabinecie stomatologicznym Centrum Medycznego Ogrodowa w Skierniewicach. Oceniono intensywność próchnicy wyrażoną wskaźnikiem PUWZ z uwzględnieniem poszczególnych składowych P,U,W (P- średnia liczba zębów z próchnicą, U- średnia liczba zębów usuniętych i W- średnia liczba zębów 
wypełnionych) oraz wskaźnik leczenia zębów WL (W/(P+W)) w zależności od wieku i płci.

WYNIKI. Udział poszczególnych składowych wskaźnika PUW był bardzo zbliżony u dzieci w wieku 6 i 18 lat. Połowę wskaźnika PUW stanowiła składowa P (50,7\% u 6-latków i 52,4\% u 18-latków), wartości składowej U były najniższe, odpowiednio ( $16,1 \%$ i $12,3 \%$, natomiast nieco ponad $1 / 3$ to składowa $\mathrm{W}$ (odpowiednio $33,2 \%$ i 35,3\%). W przypadku 12-latków, składowa P wynosiła aż 68,4\% wskaźnika PUW, składowa U to zaledwie kilka procent - 4,5\%, a składowa W - 27,1\%. Wartość wskaźnika leczenia w grupie 6-latków i 18-latków wynosiła 0,40 i była istotnie wyższa niż w grupie 12-latków - 0,3.

WNIOSKI. Istnieje pilna potrzeba monitorowania stanu uzębienia, profesjonalnej profilaktyki próchnicy i zachowawczego leczenia zębów u dzieci i młodzieży regionu skierniewickiego.

Słowa kluczowe: grupy referencyjne, próchnica, wskaźnik leczenia, dzieci i młodzież

\section{INTRODUCTION}

Dental caries is a transmissible, multifactorial chronic disease of dental hard tissues which affects a large percentage of the population (1). Numerous studies have shown that there is a correlation between caries prevalence and systemic diseases, i.e., cardiovascular and cerebrovascular diseases in newborns, diabetes, pulmonary infections, as well as various forms of cancer (2). Therefore, oral health has been constantly monitored. Age reference groups have been specified and subjected to regular dental check-ups. They include children aged 6,12, 18 years and adults aged 35-44 and 55-64 years. According to the principles of oral health monitoring adopted by the WHO, the youngest age reference groups of the population are examined every two years, and adolescents and youth graduating from high school every three and five years, respectively. The designated time intervals depend on the incidence of caries disease and its dynamics related to a particular stage of human life $(3,4)$.

On the basis of the examinations of the reference groups, it has been observed that the dental status of children and adolescents affects the general oral health of adults. Thus, periodic check-ups enable dental practitioners to evaluate the efficacy of dental care and implemented measures aimed at improving its functioning. All these factors are not without impact on the quality of patients' life in terms of their aesthetic and functional dentition $(3,4)$.

\section{THE AIM OF THE STUDY}

The aim of the study was to evaluate the state of dentition and effectiveness of treatment among children and adolescents in the reference groups aged 6,12 and 18 years from the town of Skierniewice and its region in the years 2017-2020.

\section{WSTEP}

Próchnica jest transmisyjną, wieloprzyczynową przewlekłą chorobą twardych tkanek zęba, która obejmuje duży odsetek populacji (1). Liczne badania udowodniły, że istnieje związek między występowaniem próchnicy a chorobami ogólnoustrojowymi tj.: choroby sercowo-naczyniowe i mózgowo-naczyniowe, wady u noworodków, cukrzyca, infekcje płucne oraz różne postaci raka (2). Dlatego zdrowie jamy ustnej podlega ciągłemu monitoringowi. Wyznaczono referencyjne grupy wiekowe poddawane regularnym przeglądom stomatologicznym. Są to dzieci w wieku 6, 12, 18 lat oraz osoby dorosłe w wieku 35-44, 55-64 lat. Zgodnie z przyjętymi przez WHO zasadami monitorowania stanu zdrowia jamy ustnej najmłodsze indeksowe grupy wiekowe populacji są badane co 2 lata, nastolatki i młodzież kończąca szkołę licealną odpowiednio co 3 i 5 lat. Wyznaczone odstępy czasowe są uzależnione od zapadalności na chorobę próchnicową i dynamiki procesu próchnicowego uzależnionej od etapu życia człowieka $(3,4)$.

$\mathrm{Na}$ podstawie badań grup referencyjnych zauważono, że stan uzębienia dzieci i młodzieży rzutuje na ogólny stan zdrowia jamy ustnej osób dorosłych. Cykliczne badania umożliwiają też ocenę skuteczności opieki stomatologicznej i wdrożonych działań zmierzających do poprawy jej funkcjonowania. Wszystkie te czynniki nie pozostają bez wpływu na jakość życia pacjentów $\mathrm{w}$ aspekcie estetycznym i funkcjonalnym uzębienia $(3,4)$.

\section{CEL PRACY}

Celem pracy była ocena stanu uzębienia i efektywności leczenia dzieci i młodzieży w grupach referencyjnych 6, 12 i 18 lat ze Skierniewic i okolic w latach 2017-2020. 


\section{MATERIAL AND METHODS}

The study was conducted in the years 2017-2020 and included 385 subjects: 134 children aged 6 (74 girls, 60 boys), 128 aged 12 (63 girls, 65 boys), and 123 adolescents aged 18 years (61 girls, 62 boys). Dental visits took place in the Dental Clinic at the Ogrodowa Medical Centre in Skierniewice. Dental examination, health education, qualification for dental conservative treatment and the treatment itself were performed by two experienced dental professionals (M.B-M., M.C-W.). Prior to the examination, the dental practitioners were subject to calibration, which consisted in examining the same ten patients from each index group, comparing the obtained results and arriving at mutual agreement, in the case of discrepancy between their opinions. The study involved consecutive subjects who wanted to participate in the examination. All patients and their guardians gave consent for the study. A subjective and objective examination was performed. The dentition was assessed under artificial light using a dental mirror and the WHO-621 balltipped periodontal probe. The teeth were inspected in a moist environment and, if in doubt, were dried with air syringe. The results of the dental examination were recorded in the patient's chart.

On clinical examination, the prevalence and intensity of caries were determined by the DMFT index, taking into consideration its particular components (the mean number of teeth with caries $-D$ (decayed), teeth extracted - M (missing), and filled - F) and by the dental caries treatment index DTI $=F /(D+F)$. All parameters were presented according to sex.

The obtained results were subject to statistical analysis. The Chi-square test of independence was used to compare caries prevalence in relation to sex. The Student's t-test was applied for the comparison of the mean DMFT values and its components as well as the DTI values in the groups of girls and boys. A significance level of $p \leq 0.05$ was adopted. The tables show the test values (the Chi-square and Student's t-test) and the probability of error (p). In the case of significant differences, the values are presented in bold. The mean values of individual parameters are given to one decimal place of accuracy, while standard deviations are given to two decimal places. Greater accuracy in standard deviations results from the need to visualize the differences in individual groups studied.

\section{MATERIAŁ I METODY}

Badania przeprowadzono w latach 2017-2020. Wzięło w nich udział łącznie 385 osób w tym: 134 dzieci w wieku 6 lat (74 dziewczęta, 60 chłopców), 128 w wieku 12 lat (63 dziewczęta, 65 chłopców) i 123 w wieku 18 lat (61 dziewcząt, 62 chłopców). Wizyty odbywały się w gabinecie stomatologicznym Centrum Medycznego Ogrodowa w Skierniewicach. Badanie, edukację zdrowotną, kwalifikację do leczenia zachowawczego zębów i samo leczenie przeprowadziło dwóch doświadczonych lekarzy stomatologów (M. B-M., M. C-W.). Przed badaniem lekarze zostali poddani kalibracji, polegającej na zbadaniu 10 tych samych pacjentów z każdej grupy wskaźnikowej, porównaniu uzyskanych wyników i uzgodnieniu, w przypadku rozbieżności wspólnego, obowiązującego stanowiska. Badaniu poddano kolejne zgłaszające się osoby, wszyscy pacjenci i ich opiekunowie wyrazili zgodę na wykonanie badania. Przeprowadzono badanie podmiotowe i przedmiotowe. Oceny uzębienia dokonano w sztucznym oświetleniu z użyciem lusterka i zgłębnika periodontologicznego WHO nr 621 zakończonego kulką. Zęby oglądano w wilgotnym środowisku, w razie wątpliwości osuszano powietrzem z dmuchawki. Wyniki przeglądu stomatologicznego odnotowano w karcie pacjenta.

W badaniu oceniono występowanie próchnicy, obliczono intensywność próchnicy wyrażoną wskaźnikiem PUWZ z uwzględnieniem poszczególnych składowych (średnia liczba zębów z próchnicą - P, średnia liczba zębów usuniętych - U i średnia liczba zębów wypełnionych $-\mathrm{W}$ ) oraz wskaźnik leczenia $\mathrm{WL}=\mathrm{W} /$ $(\mathrm{P}+\mathrm{W})$. Wszystkie parametry przedstawiono z podziałem na płeć.

Uzyskane wyniki poddano analizie statystycznej. Dla porównania częstości występowania próchnicy w zależności od płci zastosowano test niezależności chi- kwadrat. Porównując średnie wartości PUWZ i jego składowe oraz wskaźniki leczenia WL w grupach dziewcząt i chłopców, skorzystano z testu t- Studenta. Przyjęto poziom istotności $\mathrm{p} \leq 0,05$. W tabelach podano wartości testu (chi-kwadrat, t) oraz prawdopodobieństwa błędu (p). W przypadku istotnych różnic wartości wyróżniono tłustym drukiem. Wartości średnie poszczególnych parametrów podano z dokładnością do jednego miejsca po przecinku, natomiast odchylenia standardowe $\mathrm{z}$ dokładnością do dwóch miejsc po przecinku. Większa dokładność w przypadku odchyleń standardowych wynika z konieczności uwidocznienia występujących różnic w poszczególnych badanych grupach. 


\section{RESULTS}

The results are shown in Tables 1-5.

\section{WYNIKI}

Uzyskane wyniki przedstawiono w tabelach 1-5.

Table 1. Caries intensity expressed by the DMF index with D, M, and F components in the 6-, 12-, and 18-year-olds according to sex (mean values \pm standard deviations).

Tabela 1. Intensywność próchnicy wyrażona wskaźnikiem PUWZ z uwzględnieniem składowych P,U,W u 6-, 12- i 18latków z uwzględnieniem płci (uwzględniono średnie \pm odchylenie standardowe).

\begin{tabular}{|c|c|c|c|c|c|c|c|c|c|}
\hline \multirow{2}{*}{ Variables } & \multicolumn{4}{|c|}{ Girls } & \multicolumn{3}{c|}{ Boys } & \multicolumn{3}{c|}{ Total } \\
\cline { 2 - 10 } & $\begin{array}{c}6 \text {-year- } \\
\text { olds }\end{array}$ & $\begin{array}{c}12 \text {-year- } \\
\text { olds }\end{array}$ & $\begin{array}{c}18 \text {-year- } \\
\text { olds }\end{array}$ & $\begin{array}{c}\text { 6-year- } \\
\text { olds }\end{array}$ & $\begin{array}{c}12 \text {-year- } \\
\text { olds }\end{array}$ & $\begin{array}{c}18 \text {-year- } \\
\text { olds }\end{array}$ & $\begin{array}{c}6 \text {-year- } \\
\text { olds }\end{array}$ & $\begin{array}{c}12 \text {-year- } \\
\text { olds }\end{array}$ & $\begin{array}{c}18 \text {-year- } \\
\text { olds }\end{array}$ \\
\hline $\mathrm{D}$ & $1.2 \pm 0.6$ & $2.8 \pm 0.8$ & $5.6 \pm 1.12$ & $0.81 \pm 0.3$ & $2.4 \pm 0.7$ & $6.9 \pm 2.33$ & $1.0 \pm 0.2$ & $2.6 \pm 1.24$ & $6.3 \pm 2.8$ \\
\hline $\mathrm{M}$ & $0.2 \pm 0.1$ & $0.2 \pm 0.1$ & $1.3 \pm 0.9$ & $0.5 \pm 0.2$ & $0.1 \pm 0.1$ & $1.6 \pm 0.7$ & $0.3 \pm 0.1$ & $0.2 \pm 0.1$ & $1.5 \pm 0.9$ \\
\hline $\mathrm{F}$ & $0.7 \pm 0.27$ & $1,0 \pm 0.4$ & $3.1 \pm 1.2$ & $0.7 \pm 0.2$ & $1.0 \pm 0.6$ & $5.3 \pm 2.3$ & $0.7 \pm 0.3$ & $1.0 \pm 0.5$ & $4.3 \pm 2.1$ \\
\hline $\mathrm{DMF}$ & $2.1 \pm 1.5$ & $4.0 \pm 1.28$ & $10.1 \pm 3.4$ & $1.9 \pm 0.9$ & $3.6 \pm 1.6$ & $13.7 \pm 3.6$ & $2.1 \pm 1.2$ & $3.8 \pm 1.34$ & $12.1 \pm 3.6$ \\
\hline
\end{tabular}

Table 2. Comparison of the DMF index values and D, M, F components in age groups according to sex.

Tabela 2. Porównanie składowych P,U,W i PUWZ w grupach wiekowych pod względem płci.

\begin{tabular}{|c|c|c|c|}
\hline Variables & 6-year-olds & 12-year-olds & 18-year-olds \\
\hline $\mathrm{D}$ & $\mathbf{t}=\mathbf{4 . 6 7 3} \mathbf{p}=\mathbf{0 . 0 0 0 0}$ & $\mathbf{t}=\mathbf{2 . 8 1 8 ;} \mathbf{p}=\mathbf{0 . 0 0 5 6}$ & $\mathbf{t}=\mathbf{3 . 9 0 1 ;} \mathbf{p}=\mathbf{0 . 0 0 0 0}$ \\
\hline $\mathrm{M}$ & $\mathbf{t}=\mathbf{9 . 9 4 2} ; \mathbf{p}=\mathbf{0 . 0 0 0 0}$ & $\mathbf{t}=\mathbf{7 . 2 4 3 ;} \mathbf{p}=\mathbf{0 . 0 0 0 0}$ & $\mathrm{t}=1.639 ; \mathrm{p}=0.104$ \\
\hline $\mathrm{F}$ & $\mathrm{t}=1.184 ; \mathrm{p}=0.239$ & $\mathrm{t}=0.549 ; \mathrm{p}=0.583$ & $\mathbf{t}=\mathbf{6 . 3 7 1 ;} \mathbf{p}=\mathbf{0 . 0 0 0 0}$ \\
\hline $\mathrm{DMF}$ & $\mathrm{t}=1.641 ; \mathrm{p}=0.103$ & $\mathrm{t}=1.663 ; \mathrm{p}=0.099$ & $\mathbf{t}=\mathbf{5 . 7 7 9} ; \mathbf{p}=\mathbf{0 . 0 0 0 0}$ \\
\hline
\end{tabular}

As can be seen from the data in Tables 1 and 2, in the 6-year-old children, a statistically significant difference in the values of $\mathrm{D}$ and $\mathrm{M}$ components $(\mathrm{p}<0.001)$ was observed. A higher value of the D component was found in girls, while the $\mathrm{M}$ component was higher among boys. The number of filled teeth $(\mathrm{F})$ did not differ significantly.

In the group of 12-year-olds, it was noticed that the mean value of $\mathrm{D}$ and $\mathrm{M}$ components was significantly higher in girls than in boys ( $\mathrm{p}<0.01 ; \mathrm{p}<0.001)$. As in the group of younger age, the $\mathrm{F}$ component was not significantly different in girls and boys. The group of 18 -year-olds was characterized by statistically significant differences between girls and boys ( $p$ $<0.001$ ) in the values of D and F components and the DMF index. Significantly higher values were noted in the group of boys.
Jak wynika $\mathrm{z}$ danych zawartych w tabeli 1 i 2 u dzieci 6-letnich odnotowano różnicę istotną statystycznie w wartościach P i U $(\mathrm{p}<0,001)$. Stwierdzono wyższą wartość składowej $\mathrm{P}$ u dziewcząt, natomiast składowa U była wyższa wśród chłopców. Liczba zębów wypełnionych nie różniła się istotnie.

W grupie 12-latków zauważono, że średnia wartość P i U była istotnie większa u dziewcząt niż $\mathrm{u}$ chłopców $(p<0,01 ; p<0,001)$. Podobnie jak w młodszej grupie wiekowej składowa $\mathrm{W}$ nie różniła się istotnie u dziewcząt i chłopców. W grupie 18-latków odnotowano różnice istotne statystycznie związane z płcią pomiędzy dziewczętami i chłopcami $(\mathrm{p}<0,001) \mathrm{w}$ wartościach składowej $\mathrm{P}$ i W oraz wskaźnika PUWZ. Istotnie wyższe wartości odnotowano u chłopców.

Table 3. Percentage distribution of D, M, and F components in the DMF index.

Tabela 3. Procentowy udział składowych P, U i W we wskaźniku PUWZ.

\begin{tabular}{|c|c|c|c|c|c|c|c|c|c|}
\hline \multirow{2}{*}{ Variables } & \multicolumn{4}{|c|}{ Girls } & \multicolumn{3}{c|}{ Boys } & \multicolumn{3}{c|}{ Total } \\
\cline { 2 - 10 } & $\begin{array}{c}6 \text {-year- } \\
\text { olds }\end{array}$ & $\begin{array}{c}12 \text {-year- } \\
\text { olds }\end{array}$ & $\begin{array}{c}18 \text {-year- } \\
\text { olds }\end{array}$ & $\begin{array}{c}6 \text {-year- } \\
\text { olds }\end{array}$ & $\begin{array}{c}12 \text {-year- } \\
\text { olds }\end{array}$ & $\begin{array}{c}18 \text {-year- } \\
\text { olds }\end{array}$ & $\begin{array}{c}\text { 6-year- } \\
\text { olds }\end{array}$ & $\begin{array}{c}12 \text {-year- } \\
\text { olds }\end{array}$ & $\begin{array}{c}18 \text {-year- } \\
\text { olds }\end{array}$ \\
\hline D & 57.1 & 69.7 & 55.7 & 42.2 & 67.8 & 50.3 & 50.7 & 68.4 & 52.4 \\
\hline M & 9.9 & 5.8 & 13.2 & 24.0 & 3.4 & 11.4 & 16.1 & 4.5 & 12.3 \\
\hline F & 33.0 & 24.5 & 31.1 & 33.8 & 28.8 & 38.3 & 33.2 & 27.1 & 35.3 \\
\hline DMF & 100.0 & 100.0 & 100.0 & 100.0 & 100.0 & 100.0 & 100.0 & 100.0 & 100.0 \\
\hline
\end{tabular}


The data in Table 3 shows that the percentage distribution of the D component in the DMFT index in the groups of 6- and 18-year-olds, both girls and boys, was much lower than in the case of 12-year-olds. In this age group, the values obtained for girls were similar to those in boys ( $\mathrm{D}$ component was over $50 \%$ ). The percentage of $\mathrm{M}$ and $\mathrm{F}$ components in 6- and 18-yearold girls and boys was higher compared to 12 -year-old girls and boys.

In the group of 12-year-olds, the distribution of the D component expressed as a percentage was found to be the highest among the examined children $(67.8 \%$ in boys and $69.7 \%$ in girls). The $\mathrm{M}$ component was $3.4 \%$ and $5,8 \%$, respectively, and $\mathrm{F}-28.8 \%$ and $24.5 \%$.

Overall, among all the examined children, the percentage distribution of $\mathrm{D}, \mathrm{M}$, and $\mathrm{F}$ components in the DMFT index appeared to be very similar in children aged 6 and 18 years. The D component constituted about $1 / 2$ of the index values and was $50.7 \%$ and $52.4 \%$, respectively. The $\mathrm{M}$ component values were the lowest, $16.1 \%$ and $12.3 \%$, respectively. The F component appeared to be slightly more than $1 / 3$ : $33.2 \%$ and $35.3 \%$. In the case of 12 -year-olds, the D component was found to be $68.4 \%$. The $\mathrm{M}$ component accounted for only a few percent $(4.5 \%)$, and the $\mathrm{F}$ component for $27.1 \%$.
Jak wynika $\mathrm{z}$ danych zawartych $\mathrm{w}$ tabeli $3 \mathrm{w}$ grupach: 6- i 18-latków, zarówno u dziewcząt jak i chłopców, procentowy udział składowej $\mathrm{P}$ we wskaźniku PUWZ był znacznie mniejszy niż w przypadku 12-latków . W tej grupie wiekowej u dziewcząt uzyskano wartości podobne jak u chłopców (udział P wynosił powyżej 50\%). Procentowy udział U i W u dziewcząt i chłopców 6- i 18-letnich był wyższy niż u 12-latków tej samej płci.

W grupie 12-latków udział składowej P wyrażony w procentach był największy spośród zbadanych dzieci $(67,8 \%$ u chłopców i $69,7 \%$ w grupie dziewcząt). Składowa U, to odpowiednio 3,4\% i 5,8\%, a W $28,8 \%$ i $24,5 \%$.

Ogółem wśród wszystkich badanych procentowy udział składowych P, U i W we wskaźniku PUWZ okazał sie bardzo zbliżony u dzieci w wieku 6 i 18 lat. Około 1/2 wskaźnika stanowiła składowa P: odpowiednio $50,7 \%$ i $52,4 \%$. Wartości składowej U były najniższe, odpowiednio: $16,1 \%$ i $12,3 \%$. Nieco ponad 1/3 stanowiła składowa $\mathrm{W}: 33,2 \%$ i 35,3\%. W przypadku 12-latków, składowa $\mathrm{P}$ wynosiła $68,4 \%$. Składowa U stanowiła zaledwie kilka procent $(4,5 \%)$, a składowa $\mathrm{W}-27,1 \%$.

Table 4. The dental treatment index (DTI) in 6-, 12- and 18-year-olds according to sex

Tabela 4. Wskaźnik leczenia WL u 6-,12- i 18-latków z uwzględnieniem płci.

\begin{tabular}{|c|c|c|c|}
\hline \multirow{2}{*}{ Age } & \multicolumn{2}{|c|}{ Treatment index for permanent teeth DT=F/(D + F) according to sex } \\
\cline { 2 - 4 } & Girls & Boys & Total \\
\hline 6-year-olds & $0.4 \pm 0.15$ & $0.5 \pm 0.17$ & $0.4 \pm 0.15$ \\
\hline 12-year-olds & $0.3 \pm 0.11$ & $0.3 \pm 0.10$ & $0.3 \pm 0.11$ \\
\hline 18-year-olds & $0.4 \pm 0.13$ & $0.4 \pm 0.18$ & $0.4 \pm 0.16$ \\
\hline
\end{tabular}

Table 5. Comparison of the DTI in groups of 6-, 12- and 18-year-olds according to sex.

Tabela 5. Porównanie wskaźnika leczenia WL w grupach 6-, 12- i 18- latków według płci

\begin{tabular}{|c|c|c|c|c|c|c|}
\hline \multirow{2}{*}{ Compared age groups } & \multicolumn{2}{|c|}{ Girls } & \multicolumn{2}{c|}{ The boys } & \multicolumn{2}{c|}{ Overall } \\
\cline { 2 - 7 } & T-test value & P-value & T-test value & P-value & T-test value & P-value \\
\hline 6-year-olds with 12-year-olds & $\mathbf{4 . 6 6 8}$ & $\mathbf{0 . 0 0 0 0}$ & $\mathbf{5 . 9 8 3}$ & $\mathbf{0 . 0 0 0 0}$ & $\mathbf{7 . 1 9 8}$ & $\mathbf{0 . 0 0 0 0}$ \\
\hline 6-year-olds with 18-year-olds & 0.407 & 0.342 & 0.622 & 0.268 & 0.154 & 0.439 \\
\hline 12-year-olds with 18-year-olds & $\mathbf{4 . 6 1 9}$ & $\mathbf{0 . 0 0 0 0}$ & $\mathbf{5 . 0 3 3}$ & $\mathbf{0 . 0 0 0 0}$ & $\mathbf{7 . 0 2 9}$ & $\mathbf{0 . 0 0 0 0}$ \\
\hline
\end{tabular}

The results contained in Table 4 and 5 show statistically significant differences in the mean values of the dental treatment index between the groups of 6 -year-old and 12-year-old patients, both in the entire sample and in the sex groups $(\mathrm{p}<0.001)$. Similarly, the comparison of the treatment index in the group of 12- and 18-year-old patients revealed a statistically significant difference both in the whole group and in the sex groups $(p<0.001)$. It turned out that the DTI values were significantly higher in the group of 6 -year-olds than in the group of 12-year-olds, and also
Wyniki umieszczone w tabelach 4 i 5 pokazują istotne statystycznie różnice między średnimi wskaźnika leczenia WL pomiędzy grupami pacjentów 6-letnich i 12-letnich, zarówno ogółem, jak i w grupach płci $(p<0,001)$. Podobnie porównanie wskaźnika leczenia w grupie pacjentów 12-letnich i 18-letnich wykazało istotną statystycznie różnicę zarówno w całej grupie, jak i w grupach płci $(\mathrm{p}<0,001)$. Okazało się, że wartości wskaźników leczenia były istotnie wyższe w grupie 6-latków niż w grupie 12-latków, a także istotnie wyższe w grupie 18-latków niż 12-latków. Nie stwier- 
significantly higher in the group of 18-year-olds as compared to the 12-year-olds. However, no statistically significant differences in the value of DTI for 6- and 18 -year old patients in both the total group as well as in the group of girls and boys were observed.

\section{DISCUSSION}

The results of the conducted research showed that the distribution of the DMF index components was very similar in children aged 6 and adolescents aged 18 years. The D component value constituted half the DMF index $(50.7 \%$ in 6-year-olds and $52.4 \%$ in 18-year-olds), the $\mathrm{M}$ component values were the lowest (16.1\% and $12.3 \%$, respectively), while the $\mathrm{F}$ component values were slightly more than $1 / 3$ of the index (33.2\% and $35.3 \%$ respectively). In 12-year-olds, the $\mathrm{D}$ component was the highest among all examined subjects and amounted to $68.4 \%$. The $\mathrm{M}$ component accounted for $4.5 \%$, and the F component was $27.1 \%$. The treatment index in the group of 6-year-olds and 18 -year-olds was 0.40 , whereas in the group of 12 -yearolds it was significantly lower and equaled 0.3 .

Dental caries etiology is multifactorial. Children are particularly susceptible to this disease, due to the low degree of enamel and dentin mineralization, and thus more vulnerable to infection caused by cariogenic bacteria.

The analysis of our results indicates that the value of the DMF index was the lowest in children aged 6 years and amounted to 2.1, which results from a small number of permanent teeth at this age, usually the incisors and the first molars. The mean DMF value increased with age and equalled 3.8 in 12-year-old children; the highest value was found in the group of 18-year-olds - 12.1. The increase in the index with age is consistent with other reports (5-7).

According to our observations in 6- and 12-yearold children as well as in adolescents aged 18 years, teeth with decay (D) constituted over half the values of the DMF index. The value of this component increased with age, initially ranging from 1.0 in 6 -year-olds to 2.6 in 12-year-olds and to 6.3 in 18 -year-olds. The number of teeth filled (F) was a minor component of the DMFT, representing $1 / 3$ of the index value, which indicates that the examined patients had more teeth with cavities than restored. The values of teeth lost (M), the smallest DMF component, ranged from 0.2 to 1.5. It is worth noting that the 6 -year-olds had a greater number of teeth missing as compared to the 12 -yearolds, which can be explained by the fact that most of the examined children in the youngest age group came from low-income and large families supported by social care and the Town Office in Skierniewice. dzono natomiast istotnych statystycznie różnic $\mathrm{w}$ wartości wskaźnika WL u 6-latków i 18-latków, zarówno w całej grupie jak i w grupie dziewcząt i chłopców.

\section{DYSKUSJA}

Wyniki przeprowadzonych badań pokazały, że udział poszczególnych składowych wskaźnika PUW był bardzo zbliżony u dzieci w wieku 6 i 18 lat. Połowę wskaźnika PUW stanowiła składowa P (50,7\% u 6-latków i 52,4\% u 18-latków), wartości składowej U były najniższe (odpowiednio $16,1 \%$ i $12,3 \%$ ), natomiast nieco ponad $1 / 3$ to składowa $\mathrm{W}$ (odpowiednio $33,2 \%$ i 35,3\%). U dzieci 12-letnich udział składowej P był największy spośród wszystkich zbadanych dzieci i równał się $68,4 \%$. Składowa U wyniosła $4,5 \%$, a W 27,1\%. Wartość wskaźnika leczenia w grupie 6-latków i 18-latków równała się 0,40 , natomiast w grupie 12-latków była istotnie niższa i wynosiła 0,3 .

Etiologia próchnicy jest wieloprzyczynowa. Dzieci są grupą szczególnie narażoną na tę chorobę ze względu na niski stopień mineralizacji szkliwa i zębiny, a w związku z tym większą podatnością na infekcję bakteriami próchnicotwórczymi.

Analizując uzyskane przez nas dane, należy zauważyć, że u dzieci w wieku 6 lat wartość wskaźnika PUWZ była najmniejsza i wynosiła 2,1 co wynika z małej liczby zębów stałych w tym wieku, zwykle siekaczy i pierwszych zębów trzonowych. Wartość średniej PUWZ wzrastała wraz z wiekiem i wynosiła 3,8 u dzieci 12-letnich, największą wartość stwierdzono w grupie 18-latków - 12,1. Wzrost wskaźnika wraz $\mathrm{z}$ wiekiem jest zgodny $\mathrm{z}$ doniesieniami innych autorów (5-7).

Według naszych obserwacji u dzieci 6-, 12-letnich oraz młodzieży 18-letniej ponad połowę wartości wskaźnika PUW stanowiły zęby z próchnicą $(\mathrm{P})$. Wartość tej składowej wzrastała wraz z wiekiem, począwszy od 1,0 u 6 -latków przez 2,6 u 12-latków do 6,3 u 18-latków. Mniejszą składową PUWZ, stanowiącą około $1 / 3$ wartości wskaźnika, stanowiła liczba zębów wypełnionych (W), co wskazuje, że badani pacjenci mieli więcej zębów w stadium ubytkowym niż wyleczonych. Zęby usunięte (U) to najmniejsza składowa wartości PUWZ, zawierała się w przedziale od 0,2 do 1,5. Zwraca uwagę, że u 6-latków liczba zębów usuniętych była większa niż u 12-latków, co można tłumaczyć faktem, że większość badanych dzieci $\mathrm{w}$ najmłodszej grupie wiekowej pochodziła $\mathrm{z}$ rodzin ubogich i wielodzietnych objętych pomocą społeczną i Urzędu Miasta w Skierniewicach.

Niewiele jest doniesień, w których porównano stan uzębienia dzieci i młodzieży w grupach wskaźnikowych. Kilka z nich dotyczy osób w wieku rozwojowym $\mathrm{z}$ województwa łódzkiego, a że Skierniewice 
There are scarce reports comparing the state of dentition in children and adolescents in the reference groups. Some of them deal with children in the developmental age in the Łódź Voivodeship, and as Skierniewice is situated in the same voivodeship, the authors decided to confront their results with the data obtained in this area.

In the study by Rybarczyk of 2008, which concerned children from Łódź, the value of the DMF index was 1.5 in the 6-year-olds $(5,6)$, in our research it was higher and equalled 2.1. Considering the particular components, the number of teeth with caries observed by Rybarczyk covered the value of the entire DMF index, because both the number of teeth filled $(F)$ and extracted (M) equalled zero $(5,6)$. In children from Skierniewice, the number of carious teeth amounted to half the DMF index, $\mathrm{D}=1.0(50.7 \%), \mathrm{F}=0.7(33.2 \%)$ was a lower component and $\mathrm{M}=0.3(16.1 \%)$ appeared to be the lowest.

In the study of 2014 in Łódź concerning 12-yearold children, the authors recorded (7) that the DMF value was 1.63 . Teeth filled (1.23) were the dominant part of the index and the value of the teeth lost was satisfactorily low -0.03 . Among the 12 -year-olds in Skierniewice, the DMF index was twice as high - 3.8, and the number of teeth with caries, $\mathrm{D}=2.6$, became its greater component (over 68\%). The number of filled teeth was much lower $\mathrm{F}=1.0$ and accounted for only $27.1 \%$ of the total index value.

A number of authors (8-10) evaluated the dental status of 18-year-old subjects from the city of Łodz. The obtained data shows that the DMF value in this group ranged between 6.58 and 7.28. Hilt et al. (9) in the study of 2010 reported that $3 / 4$ of the DMF score applied to the number of the filled teeth and $1 / 4$ to carious teeth $(\mathrm{DMF}=7.27, \mathrm{~F}=5.51, \mathrm{D}=1.59, \mathrm{M}=0.17)$. In our study, subjects in this age group had significantly worse results. The DMF index score was found to be 12.1, and its highest component comprising more than half of the teeth with caries was 6.3. The filled teeth constituted only $1 / 3$ of the value, 4.3 , and the removed ones amounted to 1.5 . The data indicates that young residents of Skierniewice enter adult life with poor dentition and numerous carious teeth and some lost.

The analysis of the dynamics of caries incidence and the effectiveness of dental treatment [DT] are very sensitive indicators of dental care performance (2).

The dental caries treatment index is expressed as the quotient of the number of filled teeth and the sum of teeth with active caries and filled teeth (for permanent teeth DTI $=F /(F+D))$. On the basis of its value, which is between $0-1$, the effectiveness of the conservative treatment of dental caries can be concluded.

As our research shows, DTI was 0.4 in the 6-yearolds from Skierniewice and its region, 0.3 in the leżą na terenie tego województwa, autorki postanowiły skonfrontować swoje wyniki z danymi odnośnie tego regionu.

W badaniach Rybarczyk z 2008 roku, które dotyczyły dzieci z Łodzi, wartość wskaźnika PUWZ u 6-latków wyniosła 1,5 $(5,6)$, w naszych badaniach był on wyższy - 2,1. Rozpatrując poszczególne składowe, wg Rybarczyk liczba zębów z próchnicą pokrywała się z wartością całego wskaźnika PUWZ, bowiem zarówno liczba zębów wypełnionych (W) jak i usuniętych (U) była równa zero $(5,6)$. U dzieci ze Skierniewic liczba zębów z próchnicą stanowiła połowę wskaźnika PUWZ, $\mathrm{P}=1,0$ (50,7\%), mniejsza była składowa $\mathrm{W}=0,7$ $(33,2 \%)$ i najmniejsza $U=0,3(16,1 \%)$.

U łódzkich 12-latków w badaniach z 2014 roku autorzy stwierdzili (7), że PUWZ wyniósł 1,63. Dominującą część wskaźnika stanowiły zęby wypełnione - 1,23, a wartość dotycząca zębów usuniętych była zadowalająco niska - 0,03. Wśród 12-latków ze Skierniewic wskaźnik PUWZ był ponad dwukrotnie wyższy - 3,8, a największą jego składową (ponad 68\%) była liczba zębów z próchnicą $\mathrm{P}=2,6$. Liczba zębów wypełnionych była zdecydowanie mniejsza $\mathrm{W}=1,0$ i stanowiła tylko $27,1 \%$ całego wskaźnika.

Kilka autorek (8-10) oceniło stan uzębienia łódzkich 18-latków. Z uzyskanych danych wynika, że wartość PUWZ w tej grupie wiekowej wahała się między 6,58 a 7,28 . Hilt i in. (9) w badaniu z 2010 roku podała, że 3/4 wielkości wskaźnika PUW to wartość dotycząca zębów wypełnionych, a 1/4 zębów z próchnicą $(\mathrm{PUW}=7,27, \mathrm{~W}=5,51, \mathrm{P}=1,59, \mathrm{U}=0,17)$. W naszym badaniu u osób w tej grupie wiekowej odnotowano zdecydowanie gorsze wyniki. Wskaźnik PUWZ przyjął wartość 12,1, a największą jego składową stanowiącą ponad połowę wartości były zęby z próchnicą 6,3 , tylko $1 / 3$ to zęby wypełnione 4,3 , a usunięte 1,5 . Dane wskazują, że Skierniewiczanie wchodzą w dorosłe życie ze złym stanem uzębienia, wiele zębów objętych jest procesem próchnicowym i nie posiadają już pełnego uzębienia.

Analiza dynamiki zapadalności na próchnicę i skuteczność leczenia WL są bardzo czułymi wskaźnikami funkcjonowania opieki stomatologicznej (2).

Wskaźnik leczenia próchnicy jest wyrażony ilorazem liczby zębów wypełnionych oraz sumy zębów z aktywną próchnicą i zębów wypełnionych (dla zębów stałych $\mathrm{WL}=\mathrm{W} /(\mathrm{W}+\mathrm{P}))$. Na podstawie jego wartości, która zawiera się między 0-1, można wnioskować o efektywności zachowawczego leczenia próchnicy zębów.

Jak wynika z naszych badań u dzieci ze Skierniewic i okolic WL wynosił u 6-latków 0,4, u 12-latków 0,3 a u 18-latków 0,4. Oznacza to, że zarówno u 6- jak i 18- latków było wypełnionych $40 \%$ ubytków, natomiast u 12-latków około $30 \%$. Stwierdzono 
12 -year-olds and 0.4 in the 18 -year-olds. This means that in both 6 - and 18 -year-olds $40 \%$ of the cavities were filled, while in the 12-year-olds about 30\%. Statistically significant differences between the mean DTI value for the reference groups and for the sex groups $(\mathrm{p}<0.001)$ were detected. The treatment index was significantly higher in the group of 6-year-olds than that in 12-year-olds, and also significantly higher in the group of 18-year-olds than in 12-year-olds. In these age groups, it was significantly higher in boys compared to girls.

According to Rybarczyk et al. (5) in the study of 2010 conducted in the Łódź Voivodeship, the DTI was 0.30 for 6 -year old children, hence it was lower than in the children from Skierniewice. Rybarczyk et al. (7) reported that in the years 2008 to 2014, the DTI for 12-year-olds increased from a value of 0.57 to 0.76 , which indicates that it far exceeded the index value for the similar age group in our study (0.3). Similar observations can be made in relation to 18-year-old adolescents: Rybarczyk et al. (11) found that the mean value of the treatment index increased steadily from 0.58 in 1999 to 0.8 in 2010, while it appeared to be much lower, 0.4, in the adolescents from Skierniewice.

The data published on the basis of monitoring studies, conducted in our country in 2014-2016, shows that the treatment index for permanent teeth in the group of 6-year-old children was 0.18 on average, and in adolescents aged 12 and 18 it equalled 0.5, which indicates half of the restored teeth in these age groups (4).

Summing up, it should be stated that in the Łódź Voivodeship, more differentiated mean values of the caries intensity index and the treatment index were recorded in the same age groups. This provides information not only about dental care but also suggests insufficient health awareness of adolescent patients and their parents. The reduction in expenditure on the public dental care sector have resulted in the closure of most of the school dental offices, and any initiative associated with dental treatment has been shifted to parents and guardians (10). It should be highlighted that professional prevention of dental caries and proper models of health promoting behaviours implemented in childhood affect oral health of adult population $(8,9,12-14)$.

In the present study, the dental status of children visiting a private clinic, i.e. the Ogrodowa Medical Center, was assessed. The exclusion of reimbursed visits in connection with the specific social status of children and adolescents is a certain limitation of the study and could have influenced its outcomes. istotne statystycznie różnice między średnimi wartościami wskaźnika leczenia $\mathrm{w}$ grupach wskaźnikowych i w grupach płci $(\mathrm{p}<0,001)$. Wskaźnik leczenia był istotnie wyższy w grupie 6- latków niż w grupie 12- latków, a także istotnie wyższy w grupie 18- latków niż 12- latków. W tych grupach wiekowych był znacząco wyższy u chłopców w porównaniu z dziewczętami.

Zdaniem Rybarczyk i wsp. (5) w tym samym woj. łódzkim na podstawie badań z 2010 roku WL dla 6-latków wynosił 0,30 , był zatem niższy niż u dzieci ze Skierniewic. Odnośnie 12-latków Rybarczyk i wsp. (7) podały, że w latach 2008-2014 WL wzrósł $\mathrm{z}$ wartości 0,57 do 0,76 , co pokazuje, że znacznie przewyższał wartość wskaźnika stwierdzoną dla tej grupy wiekowej w naszym badaniu $(0,3)$. Podobne obserwacje można poczynić w odniesieniu do młodzieży 18-letniej: Rybarczyk i wsp. (11) zaobserwowały, że średnia wartość wskaźnika leczenia WL systematycznie wzrastała od 0,58 w 1999 roku do 0,8 w 2010 roku, natomiast u skierniewickich nastolatków była znacznie niższa i wynosiła 0,4 .

$\mathrm{Z}$ danych opublikowanych na podstawie badań monitoringowych $\mathrm{w}$ naszym kraju prowadzonych w latach 2014-2016 wynika, że wskaźnik leczenia zębów stałych w grupie dzieci 6-letnich wyniósł średnio 0,18 , a wśród młodzieży w wieku 12 i 18 lat równał się 0,5 co wskazuje na połowę wyleczonych zębów w tych grupach wiekowych (4).

Podsumowując należy stwierdzić, że w województwie łódzkim, w tych samych grupach wiekowych odnotowano bardzo zróżnicowane średnie wartości wskaźnika intensywności próchnicy i wskaźnika leczenia. Świadczy to nie tylko o opiece stomatologicznej, ale sugeruje też niewystarczającą świadomość zdrowotną młodocianych pacjentów i ich rodziców. Redukcja nakładów na publiczny sektor opieki stomatologicznej spowodowała likwidację większości szkolnych gabinetów dentystycznych a wszelka inicjatywa związana z leczeniem zębów została przerzucona na opiekunów (10). Należy podkreślić, że profesjonalna profilaktyka próchnicy oraz wpojone w dzieciństwie prawidłowe modele zachowań prozdrowotnych korzystnie wpływają na stan zdrowia jamy ustnej populacji dorosłych $(8,9,12-14)$.

W niniejszym badaniu oceniano stan uzębienia dzieci zgłaszających się do gabinetu prywatnego, jakim jest Centrum Medyczne Ogrodowa. Wyłączenie wizyt refundowanych w połączeniu $\mathrm{z}$ określonym statusem społecznym dzieci i młodzieży stanowi pewne ograniczenie badania i mogło mieć wpływ na jego wyniki. 


\section{CONCLUSIONS}

1. Monitoring oral health in children at different age allows dental professionals to evaluate their dentition and design preventive and therapeutic measures.

2. There is an urgent need for professional caries prevention and improvement in dental treatment effectiveness in children and adolescents of the Skierniewice region.

\section{REFERENCES}

1. Olczak-Kowalczyk D, Szczepańska J, Kaczmarek U. Współczesna stomatologia wieku rozwojowego. Wyd 1. Otwock: Med Tour Press International 2017; 87-89

2. Stanowisko Światowej Federacji Lekarzy Dentystów: Związek pomiędzy zdrowiem ogólnym człowieka a zdrowiem jamy ustnej. Czas Stomatol 2011; 64 ( 7) : 539-541

3. Monitorowanie stanu zdrowia jamy ustnej populacji polskiej w latach 2010-2012 [http:// www.dobreprogramyzdrowotne.pl/uploaded/file/ prawo/NPZ/prog monitorow jam 17052011.pdf.

4. Wierzbicka M, Szatko F, Rucińska-Szysz $\mathrm{K}$ i in. Ogólnokrajowy Monitoring Zdrowia Jamy Ustnej i Jego Uwarunkowań. Polska 2001, Ministerstwo Zdrowia, Warszawa 2001-2016; 21 (3): 181'-192

5. Rybarczyk-Townsend E, Hilt A, Lubowiedzka $\mathrm{B}$ i in. Stan uzębienia u dzieci 6-letnich w woj. łódzkim na podstawie badań z roku 2008. Nowa Stomatol 2010; 1: 9-14

6. Rybarczyk-Townsend E, Hilt A, LubowiedzkaGontarek B i in. Stan uzębienia u dzieci w wieku 6 lat $\mathrm{w}$ woj. łódzkim na podstawie badań $\mathrm{z}$ roku 2010. J Stom 2012; 65 (6) : 805-815

7. Rybarczyk-Townsend E, Hilt A, Szczepańska J. Ocena stanu uzębienia dzieci 12-letnich z województwa łódzkiego w świetle badań z 2014 roku. Przegl Epidemiol 2016; 70: 129-132

8. Królewska-Gawrzyńska J: Stomatologiczne zachowania prozdrowotne a stan uzębienia łódzkiej młodzieży 18-letniej. Nowa Stomatol 2015; 20: 153-158

9. Hilt A , Rybarczyk-Towsend E, LubowiedzkaGontarek B i in. Tendencje w zachorowalności na próchnicę zębów u młodzieży 18-letniej $\mathrm{z}$ województwa łódzkiego w latach 1995-2008. Przegl Epidemiol 2010; 64: 443-447

\section{WNIOSKI}

1. Monitorowanie stanu zdrowia jamy ustnej dzieci w różnym wieku pozwala na ocenę uzębienia i projektowanie działań profilaktycznoleczniczych.

2. Istnieją pilne potrzeby $\mathrm{w}$ zakresie profesjonalnej profilaktyki próchnicy i poprawy efektywności leczenia u dzieci i młodzieży regionu skierniewickiego.

10. Szatko F, Włostek A, Garus A i in. Bariery osiągalności opieki stomatologicznej w populacji 18-letniej młodzieży z grupy szczególnego ryzyka. Nowa Stomatol 2006; 4 : 146-153

11. Rybarczyk E, Lubowiedzka B, Wochna-Sobańska M. Ocena stanu uzębienia młodzieży 18-letniej w woj. łodzkim w roku 2004. Zdr Publ 2005; 115 (3): 287-290

12. Broniarek-Machnik M, Kunert J, BołtaczRzepkowska E. Ocena stanu uzębienia u dzieci 12-letnich z rejonu Skierniewic. Przegl Epidemiol 2019; 73 (4) : 549-556

13. Broniarek-Machnik M, Zielińska R, BołtaczRzepkowska E. Ocena stanu uzębienia u dzieci 6-letnich z rejonu Skierniewic. Przegl Epidemiol 2017; 71 (4) : 613-622

14. Broniarek-Machnik M, Suchanek-Franaszek $\mathrm{B}$, Zielińska $\mathrm{R}$, $\mathrm{i}$ in. Wiedza $\mathrm{i}$ zachowania prozdrowotne gimnazjalistów $\mathrm{z}$ woj. łódzkiego dotyczace higieny jamy ustnej. Stom Wsp 2016; 23 (6): 17-21

Received: 16.04.2021

Accepted for publication: 08.06.2021

Otrzymano: 16.04.202 r.

Zaakceptowano do publikacji: 08.06.2021 r.

\section{Address for correspondence:} Adres do korespondencji:

Małgorzata Broniarek-Machnik, DDS, PhD

Department of Conservative Dentistry,

Medical University of Lodz

92-213 Łódź, Pomorska 251

tel: (42) 6757418

e-mail: malgorzata.broniarek@umed.lodz.pl 